\title{
The Power of Institutional Legacies: How Nineteenth Century Housing Associations Shaped Twentieth Century Housing Regime Differences between Germany and the United States
}

\begin{abstract}
Comparative welfare and production regime literature has so far neglected the considerable cross-country differences in the sphere of housing. The United States became a country of homeowners living in cities of single-family houses in the twentieth century. Its housing policy was focused on supporting private mortgage indebtedness with only residual public housing. Germany, on the contrary, remained a tenant-dominated country with cities of multi-unit buildings. Its housing policy has been focused on construction subsidies to non-profit housing associations and incentives for savings earmarked for financing housing. The article claims that these differences are the outcome of different housing institutions that had already emerged in the nineteenth century. Germany developed non-profit housing associations and financed housing through mortgage banks, both privileging the construction of rental apartments. In the United States, savings and loan associations favored mortgages for owner-occupied, single-family house construction. When governments intervened during housing crises in the 1920/1930s, they aimed their subsidies at these existing institutions. Thus, US housing policy became finance-biased in favor of savings and loan associations, while Germany supported the housing cooperatives.
\end{abstract}

Keywords: Housing; Homeownership; Historic Institutions; Housing finance; Housing reform.

C O U N T R I E D O NOT ONLY FA L L into different categories of capitalist production and welfare regimes, but also different categories of housing regimes. In a capitalist country such as Germany, the entire real estate sector represented 22 percent of all existing German companies in 2006, Io percent of all employees and 8 percent of all sales, while residential real estate amounted to 59 percent of the estimated

Sebastian KoHL, Max-Planck-Institute für Gesellschaftsfordchung, Köln [ko@mpifg.de] European Fournal of Sociology, 56, 2 (2015), pp. 271-306-0003-9756/15/0000-900\$07.50per art + \$o.10 per page (C) European fournal of Sociology 2015. doi: 10.1017/S0003975615000132 
6.6 trillion euro value of German real estate in 2008 [Voigtländer et al. 2008: i-iv] and 39 percent of private net wealth [Piketty and Zucman 2013]. In spite of this sector's importance in the economy, comparative research on capitalist or welfare systems has accorded surprisingly little attention to this particular sphere of institutions, production, and welfare with the exception of specialized scholarship on housing.

Since the late i 960 s [Donnison I 967], housing scholars have offered various models for grouping OECD countries in different clusters, according to the countries' percentage of homeowners, of private and public tenants [Kemeny I98I]; their modes of land development (private, public, mixed, or anarchic) [Barlow and Duncan I994]; their degree of decommodification of housing supply [Harloe I995]; and their degree of mortgage indebtedness [Schwartz and Seabrooke 2008]. Rough correlations between types of welfare state regimes and types of housing regimes have been found [Arbaci 2007, Castles and Ferrera i 996, Hoekstra 2005]. It would be a mistake to believe that these classification attempts yielded typologies as established as those of the production or welfare regimes, and proponents of a convergence thesis with regard to housing regimes would consider any attempt at such typology as being altogether futile [Kemeny and Lowe 2005].

However, all classifications to date seem to agree that Germany and the United States fall into entirely different housing market and policy regimes, although their industrial, urbanization, and city-system developments are often comparable. Germany has been one of the countries with the lowest rates of homeownership in international comparisons. The country has densely constructed cities of apartment buildings, where land development has been municipally regulated and a great deal of subsidizing took place in the public and private construction of rental property between 1920 and the I970s. Furthermore, federal tenant protection legislation has been in existence since I9I4. For its part, the United States embarked on the homeownership path: it suburbanized its cities by encouraging the construction of single-family houses on privately developed land with the support of a subsidy scheme favoring home-owning households during the New Deal. While the German homeownership rate moved from an estimated 25.7 percent in I950 to today's level of 45.7 percent [Glatzer i 980 : 246, Zensus 20II], the US homeownership rate rose from 43.6 percent in I 940 to almost 70 percent on the eve of the last financial crisis (US Census). At the same time, federally supported public housing hardly moved beyond the 5 percent threshold of new construction, and US federal rent legislation remained entirely 
nonexistent except in moments of crisis. These are only five of the important housing-related dimensions in which the two countriesand possibly others along the English-German language dividesystematically differ.

Instead of adding to the descriptive task of typologizing, this article will directly come to grips with the question concerning the causes for the differences between the two countries in their housing regimes. Why did Germany tend to become a country of tenants with a housing policy directed at private and public rental construction? Why, on the other hand, did the United States turn into a homeownership country? The not quite obvious answer to these questions lies in the realm of historic institutionalism: I will begin by arguing that it was the type of housing-specific financial institutions that emerged in the period of strong urbanization between 1870 and I9I 4 that channeled capital into either tenant-friendly apartment buildings or homeownership-advancing single-family houses. In short, the housing form followed finance. ${ }^{\mathrm{I}}$ More specifically, the early emergence of building societies ${ }^{2}$ in the United States favored the construction of single-family houses. In Germany, this institution did not become significant until the post-World War II (WWII) era and then in a different form, while the cities of apartment buildings built during the Imperial period were mostly financed by bond-financed mortgage banks. At the same time, non-profit housing associations began constructing apartment buildings locally for the lowerincome strata. The combination of these two institutions--non-profit associations and mortgage banks--was one of the reasons why building societies of the British-American type did not arise in Germany. Note that these developments occurred in both countries prior to the first housing-related governmental interventions.

I will continue my argument by showing that the different types of housing institutions that emerged in the two countries pre-determined the way that government housing policy was designed, once the housing crises of the postwar periods and the Great Depression forced governments to react. Thus, it is not necessarily the different housing ideologies, the political system, or economic variables that account for the differences in the resulting housing policies. Rather it was the type of institutions (and their lobbies) that already had a legacy in housing provision that mattered, for governments found these most

${ }^{1}$ Borrowed from an explanation of skyscraper architecture [Willis I995].

${ }^{2}$ By the r 930 , the different names for building societies merged into the generic term "savings and loan association." For the sake of simplicity, I will refer to this type of institution as SLA throughout the text. 
easy to address. While other factors such as differences in urban planning, city history, land availability, and living standards were certainly also important for the divergent housing trajectories, I will argue for a distinct explanatory power of these historic housing institutions.

The article makes three distinct contributions. It introduces the rather neglected field of housing into the realm of comparative political economy by using some established explanatory approaches from historic institutionalism to explain housing phenomena. Then, in order to provide an institutional answer to a question that has been overlooked, it examines two empirical country cases of different housing regime types and demonstrates that housing finance is the major variable that explains their differences. Finally, the article goes beyond the arena of housing and highlights the importance of institutional legacies in explaining governmental policies. Differences in early nineteenth century reforms, for example, may become crucial in explaining governmental social policy intervention in the twentieth century.

After introducing the three different housing-related institutions -savings and loan associations (SLAs), mortgage banks, and nonprofit associations-in the following section, I will describe the origins of the SLAs in the United States (section 2). I will then explain why non-profit associations postponed the rise of an SLA type of institution in Germany (section 3). Section 4 then returns to the United States to describe what prevented the rise of a similar independent non-profit housing movement there, while section 5 explains why capital-tapping mortgage banks arose in Germany, but not in the United States. Section 6 shows how the first housing policies can be seen as perpetuating the institutional legacies in both countries rather than breaking with earlier patterns. While this section refers only to the West German and the reunified German institutional development-East German housing policy was Sovietized and later integrated into the West German housing institutions after I 989 - the previous sections refer to institutional developments before World War II in all of Germany. I conclude by generalizing the findings for other Germanand English-speaking countries and point to some implications of my findings for further research.

\section{The threefold distinction of organized housing finance circuits}

Housing, like many durable goods, requires capital investments that go beyond usual consumption expenditure and, much like larger 
infrastructural investments, requires a great amount of borrowed capital. However, compared with rates of profit to be made in other industries, housing has usually been only of secondary importance and therefore in permanent need of more capital, especially in times of general scarcity. This profitability problem is compounded by the fact that there are more people seeking long-term mortgages than there are people making long-term investments or deposits. This "maturity-mismatch" problem [Schwartz 2014b] surfaces either within financial intermediaries when they absorb short-term money to provide long-term mortgages or when borrowing households can only take out short-term mortgages, which have to be renewed more often. Traditionally until the nineteenth century, mortgage markets in most countries were organized through interpersonal networks linked by intermediaries such as notaries or lawyers. But with the growth of banks and finance in the later nineteenth century, the role of organized banking capital in the provision of mortgages became more important [Clemens and Reupke 2008; Fishback, Rose and Snowden 20I3: I I].

There were two ideal-typical ways to provide for private housing capital through banks: to create specialized local circuits of housing capital that were shielded from competition or to access larger capital markets of mostly risk-aversive investors. In the first case, that of sLAs or the German Bausparkassen (building societies), local bank deposits, often reinforced through compulsory saving plans, recruited the necessary capital for the long-term housing investment. In the second case of bond-issuing mortgage banks, the necessary capital and time commitments were obtained by maturity-matching bonds sold on capital markets and believed to be without risk. Thus, mortgage bonds constituted a product similar to those that nineteenth century investors were familiar with-the government or railroad bonds.

A third, non-profit option for providing housing capital beyond these two private banking circuits is represented by housing associations, which were founded either as philanthropic entities from above or as religiously or union-inspired cooperatives from below. Building cooperatives are owned by members who contribute capital collectively in order to have the cooperative build their housing units. In contrast to the somewhat misnamed British building societies or American SLAs-which do not build themselves but help finance members' building activities-building cooperatives constitute a separate entity commissioning or even constructing their own housing units. While members of sLAs or Bausparkassen only save money collectively but allow members to build housing units individually, 
building cooperatives pool capital to both construct and rent out units collectively. Even though they pool capital for housing construction, they are not a housing finance institution in the narrow sense but rather fulfill the role of a builder and landlord borrowing considerable sums.

The upshot of this threefold distinction of housing finance institutions into SLAs, mortgage banks, and non-profit institutions is that they do not act as a neutral channel through which savings flow into the housing sector; instead they establish selective circuits that favor either rental constructions of larger apartment buildings or small houses for owner-occupiers. More specifically, the local sLAs in American communities, much like the later German Bausparkassen, became the backbone of small-unit neighborhood housing, primarily for homeowners, while the bond-financed German mortgage banks and the non-profit movement-both absent in the United States-built dense German cities of apartment buildings. The correlation between finance institution, building type, and tenure (i.e. rental or ownership) status is never exact, but it is historically well supported and sometimes even legally prescribed. With the expansion of retail banking, banking concentration, and the end of very specialized banking beginning around I980 [Ball I990; Diamond and Lea I992], the argument grows successively weaker that housing-finance institutions have an autonomous effect on building and tenure types. Nowadays the persistence of these institutions and, more importantly, the persistence of much of the housing stock and urban structure their historic mortgage capital helped to construct suffice to ascribe these institutions a historical causal role in the creation of long-lasting housing regime differences. In the following, I will explain from a historical perspective why the United States took the SLA-dominated path, while Germany chose the path with mortgage banks and non-profits as important housing institutions.

\section{The emergence of the SLAs in the United States}

Building societies, that is, collective thrift institutions offering loans to their members, have their origins in Friendly Societies of eighteenth century England; the first known American building society, founded in Frankford, Pennsylvania, in I $83 \mathrm{I}$, is a direct outgrowth of this tradition. At first, they were usually "fully terminating," meaning 
that the society did not survive the construction of the last member's house. Towards the end of the nineteenth century, with the so-called serial plan, followed by the Dayton plan and others, sLAs became permanent institutions that opened up to serve strictly saving members in equal measure, thus competing with other thrift institutions for deposits. With these changes, the institutions were gradually transformed from member-based, cooperative-like clubs to stronger, bureaucratized bank-like institutions that did not have to rely on the thrift discipline of all individual members [Haveman and Rao I 997].

With these developments, thrifts began to differ from the German Bausparkassen, for the latter were founded as cooperatives for saving and lending to members only, in which an obligation to save ex-ante existed and it was impossible to exit without the loss of all prior savings [Block I93I], principles that persist in relaxed form to this day. This stronger emphasis on ex-ante savings and the cooperativelike identity of members and borrowers are the main features of the so-called Continental form of sLAs which spread from Germany into other parts of Europe in the interwar era [Effosse 2003: I80]. The main difference between the Continental types of sLAs and those typical of Anglophone countries is that the former do not open themselves to the capital market, beyond their members' deposits, and that members therefore have to save more capital themselves. The American sLas also did not restrict themselves to issuing second mortgages like their later German counterparts, but became the primary mortgage lending institution that gradually institutionalized the amortizing mortgage at a time when it was still common to pay mortgages back in lump sums that had been saved in mutual or savings banks. The regular payments corresponded well with the regularizing paychecks of the rising working class and were less demanding with respect to long-term foresight, while still instilling attitudes of thrift [Daunton I990: 260]. SLAs introduced this form of longer-term amortizing mortgages with relatively high loan-to-value ratios $(\mathrm{LTV})^{3}$ before the governmental insurance introduced by the New Deal standardized this type of mortgage. While amortizing mortgages or consumer installment credit has become the standard form of credit, the American situation starkly contrasts with that of Imperial Germany, where non-amortizing mortgages were dominant among the mortgage banks [Eberstadt I 920: 425].

\footnotetext{
3 The LTV-ratio indicates the percentage of the mortgage on a certain property in relation to the property's estimated value and usually

reflects the value the lender can expect to recover in a possible foreclosure.
} 
A number of conditions were favorable to the rise and spread of SLAs throughout the United States. First, on the supply side, the American banking system was still in the making in the nineteenth century. Banks moved with the frontier, and regulations often restricted banking activity to local states. SLAs were technically easy to set up, and their club-like arrangement was welcomed by Americans, who had grown weary of repeated bank failures. Although mutual savings banks existed almost to the same extent as in Europe, especially in New England and the Middle Atlantic region, they certainly did not have branches covering the entire country, and the total number of saving books was smaller than in Europe [Garon 201 2: 93]. The success of the SLAs contributed to the decline of the market share held by savings banks even in their home regions and impeded their expansion into new ones [Lintner I 948: $5 \mathrm{I}$ ] . Contrary to savings banks, the sLAs invested almost 100 percent of their assets into mortgages, not only 50-75 percent, and thus circumvented deposits in investments other than housing. Two aspects made sLAs the more adaptive type of banking institution outside of the northeast: partially compulsory savings plans were standard at SLAs, and their members had a strong role in governing the institution, as opposed to banks controlled largely by civic-minded philanthropists.

Moreover, the sLAs occupied a market niche in the growing banking market. The US postal savings banks, competitors for collecting small savings, did not develop until the twentieth century, while life insurance companies preferred to finance mortgages on farms or commercial property and national banks did not enter the mortgage business before I 900 [Snowden 2003: I64]. Commercial banks did not tend to be an option for most mortgage-seekers because they were specialized in short-term business loans [Behrens I952]. Both on the deposit-collecting side and the mortgage-lending side, the sLAs thus encountered far less established structure and competition than their counterparts did in continental Europe, where institutionalized banking had a longer history. Compared with other banks, sLAs traditionally had the advantage of low transaction costs-for members administrated themselves, at least initially-and of better information and sanctioning mechanisms concerning borrowers, as is shown in the relatively low foreclosure rates recorded in the first SLA survey in 1893 [Mason 2004: 29]. In the late I 880s, a group of nationally operating SLAs-referred to as the nationalsarose, aggressively serving mostly cities of low sLA density. They made higher profits by serving high-interest areas and cutting back 
administrative costs. Both the real estate crisis of the $\mathrm{I} 890 \mathrm{os}$ and personal profit-seeking led to the demise of this temporary phenomenon within the same decade, further strengthening the SLAs' commitment to localism.

Second, there was a specific demand for these institutions beyond the supply-side factors discussed above. SLAs filled a social niche in the nineteenth century banking market since workers, women, and immigrants were hesitant to enter the higher sphere of commercial banks, whose services specializing in short-term credit were not in any case tailored to their needs [Bühler I 965: r6; Mason 20I4]. The sLas in a city were often as fragmented as its ethnically or occupationally segregated neighborhoods. More generally, sLas were a local selfhelp response to the urban lack of capital and credit and to the resulting high interest rates that characterized much of the Western regions in the nineteenth century. Their diffusion could not be taken for granted, however. Some urban centers, such as St. Louis or New Orleans, were entirely devoid of a local SLA in I 880 [Snowden 2003: I66]. In addition, it was not only ethnic or class separatism that drove the emergence of new sLAs, but other factors as well, such as the instrumental role of realtors in creating new financial institutions to extend access to credit and to increase demand in their markets [Snowden i 997].

Third, sLAs constituted the institution that was probably most congenial to the ideas described in frontier literature: "[T]he terminating plan was the material realization of a theory of thrift based on the pillars of mutual cooperation and external control" [Haveman and Rao I997: I62I]. The image the sLAs projected through early pamphlets such as Edmund Wrigley's The Working Man's Way to Wealth-where he counts on every working man becoming his own capitalist-or in the advertisement campaigns of the United States League of Local Building and Loan Associations from I 900 onwards was that of a quasi-religious movement, not an industry, that was on the side of populists, small farmers, and community businesses in that it fought back against the big monopolies. This image also served to legitimize the sLAs' exemption from corporate taxes in 1894 [Mason 2004: 74]. While the big corporate entities served as one common enemy, any kind of more collective form of cooperation, such as the socialist experiments with production cooperatives inspired by Owen or Fourier, were equally condemned [Bodfish I93 I: 2]. Generally the joint ownership of housing facilities had a very poor reputation. It thus became difficult to establish modern apartment living for the 
upper middle classes as it was denounced as being communist [Cromley I 990: 20; Wright I983: 145].

Finally, the SLA was also supported by quite a variety of promoters, which made it a flexible partner in various coalitions. First of all, it was "promoted with missionary zeal by a vocal group of 'building and loan men' [local real estate businesses] who extolled homeownership as the means by which workers could better themselves and their communities" [Snowden 2003: I70]. A second external promoter was found in the Progressive movement and among housing reformers who also appreciated the sLAs' role in integrating immigrants and decentralizing government. Ironically, Progressivist values seemed to have promoted the adoption of the Dayton plan in the SLAs that opened them to external savers and borrowers and whose increased flexibility made more professional management necessary. As a result, sLAs went from being community clubs to becoming trusted banking institutions [Haveman, Rao and Srikanth 2007; Zucker I986].

The sLAs' causal role in furthering homeownership is hard to deny at first: they raise new capital and actually make it accessible for the purpose of constructing owner-occupied, single-family homes. The great majority of their mortgages flow into financing family homes, and their promotional activity, jointly with the realtors' organizations, has been said to create a greater demand for homeownership. Even if many of the awarded mortgages have also gone toward the construction of rental units, the dominance of the single-family dwellings smoothed the way for easy conversions to owner-occupied units later. Moreover, much single-case historical evidence from the period between I 890 and I 930 suggests that the rising number of sLAs, their growing membership, and increasing assets in mostly urban areas were behind the rise in the mortgage indebtedness that special censuses in I 890 and I 920 revealed. The decline of the national percentage of homeownership through urbanization was also beginning to be compensated by rising urban homeownership rates [Snowden 2006b]. In the Lynds' study of “Middletown” [ I 929: r 04f], for instance, SLAs come into play from i 889 onwards and were estimated to finance 80 percent of new construction in this town, in which single-family homes built of wood were the predominant type of dwelling; 85 percent of SLA members had a working-class background, and overall mortgage indebtedness was growing.

This anecdotal evidence often cited about the SLAhomeownership nexus, which even found its way into popular 
culture through Frank Capra's I 946 film It's a Wonderful World, can be supported by a more systematic regression of the sLAs' mortgage-market share on the percentage of single-family homes in 50 American cities in the r930s. The unique historical data come from two surveys undertaken by the Civil Works Administration in the r930s, namely the Real Estate Inventory and the Urban Financial Survey.

The following ols regression includes typical explanatory variables associated with the predominance of single-family homes, particularly the city's size, its geographical location, demographic composition, and economic position. Car ownership should control for the degree of suburbanization. The percentage of sLAs in the mortgage market, controlled for mortgage interests, has a significant effect on the predominance of single-family homes in the housing stock; the overall regression explains 66 percent of the variance.

TABLE 1

OLS $(n=50)$. Dependent variable: percentage of single-family house structures in housing stock

\begin{tabular}{|c|c|c|c|}
\hline & Coefficient & Std. Error & p-value \\
\hline Constant & I $46.395^{* * *}$ & 39.6539 & 0.00070 \\
\hline $\begin{array}{l}\text { SLA share in first } \\
\text { mortgages }\end{array}$ & $0.16543^{8 *}$ & 0.0975575 & 0.09810 \\
\hline Latitude & $-0.996878 * *$ & 0.425269 & 0.02440 \\
\hline Longitude & -0.243584 & O.1 82909 & o. 19088 \\
\hline Autos per family & 2.09064 & I 2.5673 & 0.86876 \\
\hline Share wooden construction & $0.200859^{*}$ & O.IOI 748 & 0.05567 \\
\hline $\begin{array}{l}\text { Average value one-family } \\
\text { dwelling }(\$)\end{array}$ & $-0.00820416^{* * *}$ & 0.00247523 & 0.00203 \\
\hline Owner income I933 (\$) & -0.000620684 & 0.00752483 & 0.93469 \\
\hline Rent-to-income I 933 & -0.452844 & 0.726026 & 0.53653 \\
\hline $\begin{array}{l}\text { Effective interest rate for } \\
\text { owners }\end{array}$ & $-7.034 I^{* *}$ & 3.43947 & $0.0478 \mathrm{I}$ \\
\hline Total buildings & -2.3 I $967 \mathrm{e}-05$ & $4.2 \mathrm{I} 4 \mathrm{I} 2 \mathrm{e}-05$ & $0.5^{8} 523$ \\
\hline Population under 20 years & O.I 739 I 8 & O. I I I392 & O. 12674 \\
\hline $\mathbf{R}^{2}$ adjusted & 0.66 & & \\
\hline
\end{tabular}

Source: See text. 


\section{The development of German non-profit associations and the belated emergence of Bausparkassen}

While a large network of local sLAs had developed in the United States and in most English-speaking countries by the I 920 , Germany and much of the European continent did not begin to develop a similar institution until the interwar period. The idea of encouraging thrift in workers by having them join an SLA for the purpose of becoming the owners of their own homes was historically not unknown in Germany. The conservative reformer Victor Aimé Huber mentioned the institution for the first time around 1850 , and both national-liberal reformers like the statistician Ernst Engel and members of the liberal Kongress deutscher Volkswirte (Congress of German Economists) spoke in favor of it [Müller I999: 48ff]. Very few examples of sLas in Germany, however, are reported prior to their successful establishment in the form of the Bausparkassen in the i920s. In the two individual cases of SLA institutions of the Anglo-American type, the sLAs ultimately failed because members did not pay contributions regularly and because they generally lacked capital [Müller ı 999: 54f].

One central reason for this modest development lies in the early and widespread development of Sparkassen (municipally controlled savings banks) in more urban regions and of credit cooperatives for the middle classes, the rural Raiffeisen banks and urban Volksbanken. From the I 860 s onwards, these institutions maintained a closely meshed net of deposit-collecting branches covering most of Germany's potential savers. By wwi, there were more than 3, , o Sparkassen, the rural cooperatives had almost two million members, and there were more than 2,000 urban cooperatives with over a million members [Kluge I99 : 89]; in I884, the national postal banks constituted yet another branch-based rival to attract small savings. By I9I4, roughly I9, 000 credit cooperatives constituted the largest part of the cooperative movement [Aschhoff and Henningsen I995: 30]. The founders of both types of cooperatives, Schulze-Delitzsch and Raiffeisen, were motivated by liberal philanthropy and social Catholicism to include low-income classes in the financial system; in doing so, they absorbed the clientele of potential sLAs. In contrast to the SLAs, the professionalization of cooperatives, however, transformed them more into small, agriculturally oriented business institutions for the middle classes, who were predominantly the borrowers of cooperatives, whereas 
workers were involved in credit cooperatives as savers at the most; skeptical attitudes of organized labor towards the cooperative movement in particular and consumption credits more generally may also have played a role [Kluge I 99I: I I3].

Daunton [I988] shows for the British case that workers rather turned to friendly societies, insuring against basic life risks, rather than to homeownership-promoting sLAs. Similarly, one reason for the absence of German sLAs lies in the existing network of insurance funds, mostly organized by professional groups and remnants of guild-based welfare systems. These funds served to protect their members from the most basic misfortunes of life-accidents, old age poverty, burial expenses (burial funds were already founded in the i 830 os [Schneider I989: 23]) - and channeled savings that could have possibly financed housing in a different direction. Already by the I870s, these funds were attracting two out of roughly four million industrial workers [Kaelble I 99I: I22], before Bismarckian compulsory insurance schemes were set up. In turn, the latter provided 6.8 million citizens with health insurance, I I.5 million with disability insurance, and I 6.5 million with accident insurance for a total contribution of 242 million Reichsmarks by i 89 i [Reuter i 980].

Private Bausparkassen did not exist in Germany prior to the I920s, when they were founded by petty bourgeois land reformers. These institutions were soon complemented by public Bausparkassen established by the Sparkassen, which used them to cover riskier second mortgages on top of their own primary mortgages. This confirms the view that existing banks preempted the rise of the SLA. The specialization on second mortgages was stipulated by law for all Bausparkassen in the I930s. This institution, much like the sLAs, linked housing savings to investments in owner-occupied housing units. A calculation of Pearson's correlation coefficients for the volume of per-capita deposits or mortgages in Bausparkassen and the homeownership rates in the various German federal states (Länder) in I 993 and 2000 , for instance, results in values of above 0.6 .

From the 1850 on, at a time when sLas were emerging in the United States, Germany saw the development of the non-profit building association as an increasingly more common institution for financing housing [Bühler ı 965: I I]. Until ı 889, non-profit building associations were usually founded from above in the legal form of limited dividend companies, even with the Prussian king as protector and capital donator. The reformist origin of many of these companies guaranteed them a certain access to capital, which was always in short 
supply; the lack of capital was also the reason why the original plan to spread homeownership among German workers by way of a rentto-buy scheme often ended up in the more cost-effective creation of non-profit rental units [Zimmermann I99I: 66], much lamented by reformers who sought to attain a home-owning working class through British-like building societies [Sonnemann and Lange i 865]. The Berliner gemeinnützige Baugesellschaft (Berlin Non-Profit Building Society) of I 848 , for instance, owned many buildings with up to ten dwelling units [Jenkis I 973: 66]. Private capital was not available since mortgages on privately financed rental housing, which were offered as securities by the private mortgage banks, could offer much higher returns than the 4 percent philanthropy. But often workers were not willing to tie their capital to limited-dividend societies or cooperative shares because this increased housing costs and decreased labor mobility [Jenkis I 973: 97].

Cooperatives were the legal form more apt to be founded from below, yet they were also haunted by the legal insecurity concerning the liability of cooperative members for cooperative debt beyond their initial contribution. Whereas early housing cooperatives were almost exclusively directed towards the mutual provision of small, privately owned houses, the Spar- und Bauverein Hannover of I 885 constituted the first cooperative devoted to raising capital for the construction of rental units through savings deposits [Jenkis I973: $\mathrm{I} 35 \mathrm{ff}$ ] and thus heralded a division in the movement between the homeownership- and the renting-direct cooperatives, with the latter becoming majoritarian.

In I889, a new Cooperative Law (Genossenschaftsgesetz) was passed, which represented a breakthrough for worker cooperatives, for example, because it restricted the liability of cooperative capital. In the same year, old age and invalidity insurance was introduced, and its funds were soon to be used for social purposes favoring the insured [Tennstedt I98I: I 87]. Both the number of cooperatives and the size of their membership grew. They were eagerly given land grants by municipalities, which were thus largely able to withdraw from the business of constructing housing themselves. There is evidence indicating that the I880s were a time when Germany stood at the crossroads of the paths leading either to the cooperatives or to the SLAs. It was also when the reformist pastor Bodelschwingh founded the "Bausparkasse for everybody" and thereby coined the generic name of the specialized banks that is used today [Müller I999: 57]. What finally pushed Germany down the road to cooperatives was the persistent lack of capital of SLAs, the far too unrealistic projects of homeownership promoters and the eventual rise 
of the competing cooperatives thanks to social security funds. The complementary relationship between the funds collected through the compulsory social security schemes and the non-profit housing associations-non-profit associations could receive cheap credit to construct rent-restricted units for lower-income classes-was not directly intended: it was not anticipated by the legislators and was included in the law rather by accident. At first, social insurance funds did not receive any instructions about the criteria to be used for distribution other than the stipulation that the companies had to be non-profit [Bullock and Read i985: 23If]. As a consequence, a steady $3 \mathrm{I}$ to 44 percent of the workers' social security funds or a total of 3.2 billion Reichsmarks between I 895 and I9I3 [Reuter I980]-augmented by the financing by the separate white-collar insurance of their own housing cooperative Gagfah in I9I I-went into workers' housing, much of which was allocated to the growing limited-dividend companies and cooperatives. While the institutions receiving these funds were only responsible for some 5 percent of the overall pre-wwi housing stock-albeit with much higher percentages in the cities [von Saldern I979] - they laid the institutional groundwork for the large non-profit and municipal ownership of 23.3 percent of all housing units in 2006 [Voigtländer et al. 2008: 21].

\section{The absence of a strong non-profit housing movement in the United States}

Writing in hindsight during the I930s, the American housing reformer Catherine Bauer remarked that a real housing movement comparable to the European one had been traditionally absent in the United States [Bauer I974]. It is true that the non-profit idea of housing had not been entirely absent. The major center for limiteddividend companies and cooperatives was the northeast, especially the city of New York, where the first philanthropic housing associations constructed moderate-income housing in the late nineteenth century [Siegler and Levy i987]. In I876, the first American housing cooperative for building apartment houses was founded, but its legal status was such that it catered to upper-classes seeking to live in jointly managed apartment houses. The first cooperative in the European sense-where a joint endeavor is made not only of the purchase of material and construction of houses but also of the 
management of the constructed units- did not arise until i9i6, when Scandinavian immigrants imported the cooperative idea from their homelands to New York City [Karin I 947]. In these cooperatives, individuals only held shares equal to the value of their occupied housing unit, whereas the cooperative itself held the title over the entire property, which often included common amenities beyond the individual units. This cooperative form, which still makes up a considerable part of Scandinavia's housing stock is much closer to private homeownership than Continental cooperative forms, where the cooperative does not require the purchase of shares equaling the sales price and where it acts more like a large non-profit landlord.

Yet, in spite of the closeness of American cooperatives to private homeownership, this associational form also did not gain much ground as a potential competitor to the sLAs. "The United States Bureau of Labor Statistics discovered only forty cooperative housing societies in existence during the mid-I920s. All but two of these were in New York City," where most of these were apartment houses inhabited by Scandinavian immigrants [Lubove i 963: 69].

One reason for this absence certainly lies in the less rapid and different development of the cooperative movement in the United States more generally. Whereas today the American cooperative economy appears to be larger and even has a stronger membership base than in European countries such as Germany [Battilani and Schröter 2012], the movement's form and beginnings were quite different. While cooperatives were developed in European countries especially for consumption, credit, some production, and then housing, these manifestations remained rather rare in nineteenth century America. The most fertile ground for such institutions was rural America, where the various populist farmer movements nurtured the existence of purchase, production and sales cooperatives [Horsthemke I998]. The United States' reputation as a "nation of joiners," as observed by Tocqueville, Schlesinger, Putnam and others in reference to Americans' strong tendency to join associations, derives more from the popularity of (quasi-) religious clubs and movements than from any efforts to do business jointly as a cooperative would [Skocpol, Ganz and Munson 2000]. The reasons for this systematic difference are complex, but they probably have to do with the prevailing private business solutions and an aversion to too much top-down philanthropy, which was associated with many cooperative institutions. In fact, many of the reasons explaining the restricted development of socialism in the United States might equally explain the 
relative lack of cooperatives. Cooperative ideas and realizations were certainly not absent in America and especially the northeast witnessed the rise of Raiffeisen-inspired credit unions, consumer and eventually housing cooperatives. The early socialist ideas of Owen, Fourier, or others had even motivated the founding of entire utopian towns, whose survival rate proved, however, to be very low [Benevolo I97I]. American housing cooperatives, which were created from the late nineteenth century onwards, lacked the vital, sustained support of three key groups: reformers, labor, and eventually the government. Such support was essential if they were to thrive like their German equivalents.

\section{Reformers}

Prior to the second generation of housing reformers such as Catherine Bauer, Edith Wood, or Lawrence Stein from the I920s onwards, American turn-of-the-century reformers did not promote non-profit housing as a real alternative model to the private tenement evils that were the target of much reformer activity [Daunton I990: 257]. Early American housing reformers were certainly aware of European tendencies, where overcrowding, congestion, and slum problems had a longer history. Prior to wwI and again between the wars, city planners and housing reformers would cross the Atlantic from the United States to Europe, and particularly Germany, when looking for new solutions [Rogers 1998]. American housing reformers either proposed the suburban-family retreat [Fishman I987: I2I], offered model houses at low, philanthropically subsidized 5-7 percent interest rates [Lubove i 962: 34], tried to educate immigrants and workers to help them achieve middle-class living standards in the Settlement House Movement, tried to improve tenement living through tenement commissions such as those headed by Lawrence Veiller in New York [Lubove i 962: I05] or else attempted to uplift downtown areas and populations with outstanding public buildings in the City Beautiful movement [Sutcliffe I 98 I: 98, r ०8]. In all of these different reformer circles, the absence of non-profit rental housing with decent standards can be considered a negative common denominator. European reformers often sought to extend access to decent middle-class rental facilities to the working classes; American reformers usually rejected that idea from the start.

When reformers of the European type-those associated with Edith Elmer Wood, Catherine Bauer, and generally the members of the Regional Planning Association of America (RPAA)-did emerge about 
the time of wwi, they could not count on equal support at the municipal, state and federal levels [Von Saldern r 997: 8I]. The suggested creation of institutions ranging from national housing banks to municipal land banks in the legislation proposed by Wood in I9I3 reveals this institutional void [Lubove I963: 27]. After Wwi, the United States "lacked any governmental machinery to compensate for the collapse of the private building industry, which had assumed exclusive responsibility for satisfying the nation's housing needs" [Lubove i 963: i 8].

\section{Labor}

Reformers did not adhere to the idea of non-profit housing subsidies benefitting the lower-income classes, and the mainstream American labor movement was equally disinterested. In European countries, cooperative movements and especially the labor movement collaborated with the housing cooperatives by acting as financial sponsors, organizers, member spill-overs, or even very directly as builders. Socialism and labor movements were, of course, not entirely absent in the United States, especially prior to wwI. Indeed, the Socialist Party of America was much in favor of social municipalism as practiced in Europe. But it was certainly weaker and less well organized than its German counterpart; in particular, the surviving and politically relevant elements exhibited different, often outright pro-capitalist political attitudes.

Private ownership of land has never been fundamentally challenged in the United States, and the critique of large land monopolies or of effortless land gains considered by many to be illegitimate did not lead to effective demands for municipal or state ownership of land or other kinds of land distribution beyond the market as it did in Germany or the United Kingdom [Daunton 2007]. Rather, the dominant reaction was to put restrictions on monopolistic speculators in favor of a more equal distribution of land so as to make everyone a participant in the market. Even Eugene Debs of the Socialist Party proposed more small landownership as a counterbalance to the big corporations [Fitrakis I 990: 24]. These ideas, taken up in the first Land Ordinance from I 785, the Homestead Act of 1862, and the r 920 s Zoning Ordinances, were repeatedly defended, first with regard to agrarian land for farmers, then in the second half of the nineteenth century for urban land for industrial workers as well. Both farmer groups and labor unions were often sympathetic to each other's concerns and used a similar vocabulary. 
For example, the Knights of Labor, whose strongly Irish and Catholic constituency affiliated itself with the fight for land reform in Ireland, included the demand for a free distribution of land to the people in the preamble of its program in 1878 [Schratz 20II: 30]. But also the American Federation of Labor (afl) was in favor of homeownership and better housing for unionized workers, as is documented in various proceedings from its annual conventions.

There are several reasons why American labor preferred homeownership. One reason, also cited in the debate about the absence or decline of socialism in the United States, is the exceptional culture of the American frontier that provided easy access to property [Foner I 984: 60, Harris and Hamnett i 987, Lipset and Marks 2000: 24, Turner I 920]. A second reason for American labor's affinity to homeownership and indifference towards non-profit housing lies in the factual housing conditions. Urban historians generally report higher homeownership rates for workers than for the middle classes before I 900 , when cities were not yet socially segregated and the middle class had not yet made the form of tenure a status norm [Garb 2005; Simon i 996; Zunz i 982]. A third reason for labor's adherence to the homeownership ideal lies in its association with populist farmer groups. Contrary to Germany [Puhle I 975: $33 \mathrm{ff}$ ], industrialism aroused various movements of small farmers such as the populist movement that served as examples to the labor movement, kept ideas of egalitarian landownership alive, and fostered fraternization against common enemies such as big monopolies, regressive taxes, and tight monetary policy [Hays I 957: 28f, Prasad 2012: I 25ff]. Finally, smaller types of housing such as single-family houses, two-story tenements, or even triple-deckers, meant that less minimum capital was necessary if one wanted to invest in housing than was the case in Germany, where apartment buildings were made up of at least half a dozen inseparable housing units. In times of hardship, one survival strategy of American labor was to invest in owner-occupied housing while renting out parts of it to earn an additional income [Harris I 989].

\section{Government}

Finally, the various levels of government largely abstained from initiating or supporting this kind of housing provision before explicit housing policy started in the r930s. American municipalities lacked the tradition of municipal land-banking, which would have helped 
cooperatives receive implicit subsidies through land provisions and would have solved their location problem, given the rise of ever more excluding neighborhoods. The provision of municipal housing lay even farther beyond the possible competences of American cities. Nor did the federal government, which subsidized homesteads, railroads, and farming through cheap land sales, become involved in subsidizing non-profit housing associations with land grants. There was no parallel in the early twentieth century United States to the German social insurance system, so there was also no substantial pool of this kind from which funds could have been drawn for non-profit purposes to subsidize low-income rental housing; this situation was decidedly different from the one in Germany.

Thus, due to the lack of support by reformers, labor, and the government, a wider non-profit housing movement did not arise in the United States, while saving institutions specializing in housing did. Once the sLAs were in place, they also constituted an essential element of a private real estate lobby that prevented the allotment of any government money to competing institutions and made life for American housing reformers more difficult [McDonnell I957].

\section{Why mortgage banks emerged in Germany and failed in the United States}

The origins of modern German mortgage banks, the oldest institution of the modern mortgage market, reach back to the aftermath of the Seven Years' War (I756-I763), when Prussian rural noblemen were in urgent need of capital [Clark 2007: I94ff]. Frederick the Great obliged local landholders to enter associations of debtors, the Landschaften, in which both the individual properties and all landholders in person mutually backed a mortgage bond that the individual debtor himself had to sell in order to receive capital. "In exchange for the compulsory membership, all members of the Landschaften held a 'right to credit,' so the Landschaft could not discriminate against individual estates. Therefore, a key to prevent adverse selection was the determination of the credit limit and the correct assessment of the estate to guarantee collateral"; the assessors were even personally liable for losses due to assessments that were too generous [Wandschneider 20I3: I I]. These conservative lending standards and trust in the monitoring of the local landholders enabled the holders of larger estates to enter into considerable mortgage debt, whereas 
small landowners were usually discriminated against in these Landschaften. It also meant the creation of an organized credit system in times when personal loans were still the most common form of credit, and it established a special circuit of finance for largely agricultural purposes. The Landschaften maintained roughly 20 percent of the mortgage market, predominantly in rural areas, and served as a model for Scandinavian mortgage banks and the French 1852 Crédit Foncier, which in turn became the model for the German mortgage stock banks: private banks issuing first mortgages to individuals that were held on their books and financed through the sale of bonds (Pfandbriefe) of matching duration [Schönmann I993: 826ff].

Mortgage banks were not permitted prior to the 1850 os because the Prussian state feared another strong rival for its state credit next to the growing railway and industrial bonds [Redenius 2009: 73]. Most of the mortgage banks were then founded between I 862 and 1872 as private stock companies to finance the expanding construction in urban areas. In 1872 , mainly agricultural forces successfully pressured the government to harmonize the different mortgage laws and allow for interstate credit flows in Germany [Eberstadt r 920: 387]. "Whereas in ${ }^{8} 865$ the volume of private mortgage bank mortgages amounted to the modest sum of 66 million marks, with Landschaften reaching 470 million, in 1900 it had increased to 6.9 billion, exceeding the Landschaften (2.2 billion) threefold" [Redenius 2009: 76, transl. by author]. Prussian ordinances regarding mortgage banks prescribed highly conservative lending, which thus strengthened banks from more liberal southern states. With the advent of troubled banks and market transparency problems, the government then enacted the 1899 federal law that legally established mortgage banks as the only issuer of Pfandbriefe (only abolished in 2005); their practice of lending at a maximum of 60 percent LTV underpinned their reputation as the provider of long-term investments that were as stable as government bonds [Schmidt I993: I026ff]. Since Pfandbriefe were traded on German stock exchanges, mortgage banks did not need to be situated in the lending region nor issue Pfandbriefe there. Indeed, the expansion of Berlin and other Prussian cities was largely made possible at first by non-Prussian banks [Eberstadt I90 : I40].

The roughly 40 private mortgage banks grew to be the biggest financer of private urban construction in Imperial Germany, with 95 percent of their mortgages being made in cities. Undoubtedly, the mere economics of more expensive urban land and the corresponding demand of clients for apartment-building mortgages shaped their 
business, but some characteristics of their own made them a functional complement to private apartment-building construction. First, whereas mortgage banks issued bonds in relatively small shares to attract greater demand among institutional investors and the wealthy bourgeoisie, they preferred to issue mortgages of higher nominal values. Contrary to the other major source of mortgage finance in Imperial Germany, namely the local savings banks (Sparkassen), mortgage banks could not count on a diversified network of branches to serve small customers with amortizing mortgages [Eberstadt I920: 424f]. The administrative costs for smaller mortgages and regular amortization payments (and non-payment sanctions) would have been much higher. Moreover, the relatively frequent trade in land or apartment buildings made non-amortizing mortgages more attractive as they could be passed onto the buyer more easily (ibid. 402]. Second, contrary to cooperative banks or Sparkassen, mortgage banks were not tied to investments in certain regions. Their lack of a branch system implied less knowledge of local conditions, and it is evident in their evaluation guidelines that they even mistrusted local evaluators, fearing they were possibly corrupt [Frederiksen I 894b]. Instead, mortgage banks had to rely on more standardized ratings based on the most standardized product in urban construction - the apartment building-while otherwise following conservative lending standards [Faller 200I]. The stereotyped rental building, much criticized from architectural and city-planning points of view, served the purposes of the banks much better. Third, since mortgage banks had to pay continued interest on their bonds-as codified in the mortgage banking law-they were strongly inclined to issue loans on income-generating objects, the best of which were apartment buildings with their continuously flowing rent payments [Frederiksen I 894a: 233, VDH I 999: 39]. The granting of mortgages for single-family homes was an exception to this practice that was only found in the German southwest [Fuchs I 929: 47]. The mortgage banks thus became major players in the organized mortgage market that were at least as important in Germany as the sLAs were in the United States, but they financed apartment buildings, not single-family houses.

Mortgage banks could not have flourished, of course, without the demand created by long-term bond investors or without the existence of a landlord class willing to own and manage real estate. This class was mainly made up of many small owners, often from the petty bourgeoisie, who invested surplus profits from small companies in city property. Possibly, the relative insignificance of stock investments for the German middle classes was a reason why these classes invested in 
mortgage bonds and real estate. Highly organized already during the Imperial period, this landlord class became an important pillar of the housing market and a strong interest group for liberal rent legislation. They were a part of the old middle classes, the Mittelstand, which conservative political groups courted from the i 890 s onwards [Unterstell i 989]. Thus, private landlords could count on fewer post-WwI rent restrictions than in neighboring countries [Führer I 999] and later became addressees of tax subsidies and depreciation allowances [Voigtländer 2009]. At the same time, the I 920 s witnessed the first attempts at national tenancy legislation which-though opposed by landlords-also made renting permanently attractive for tenants. Both the political support for private landlords and the national tenancy legislation distinguish Germany from the United States and guaranteed credit demand for mortgage banks.

In the US, on the contrary, bond-issuing mortgage banks preferring income-generating rental objects did not succeed. "Mortgage securitization appeared in six different forms between I 870 and I 940, and each time the market for mortgage-backed securities grew rapidly for a few short years and then collapsed" for largely two reasons [Snowden I995b: 262]: only unstable private mortgage banks without a statesupported structure arose, and financial regulation preventing defaults and over-lending crises remained nonexistent [ibid. 275]. "The major problem was the informational asymmetry between bondholders and

F I G URE 1

\section{Pre-Wwi mortgage market volumes in million marks}

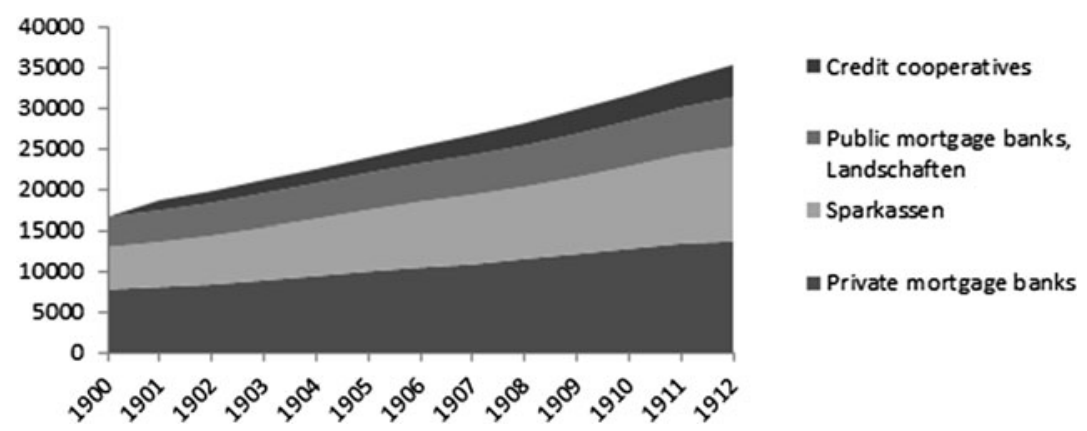

Source: [DeutscheBundesbank 1976] via Gesis; volume of Pfandbriefe for the public mortgage banks; Sparkassen-mortgages calculated as Prussian percentage of mortgages as part of German Sparkassen assets; all credit volume for the credit cooperatives. 
lenders. Many mortgage banks exploited their informational advantage by placing high-risk, high-interest loans behind the bonds" [Lea I 996: I 58]. When a capital market for secondary mortgages was eventually created in the I930s, it was built on the existing system of mortgagelending, which was dominated by the mortgages for single-family houses awarded by deposit institutions such as the sLAs.

Most of the attempts prior to the I930s concerned farm mortgages in times of new settlement in the 1880 s and of production extensions such as WwI or farmers' indebtedness problems in the r920s [Snowden 2007]. The first national securitization system, instituted by the Farm Loan Act of i 9 16, deserves mention as it anticipated the latter urban mortgage securitization for the case of farm mortgages [Prasad 201 2: I 99]. The Act created a Federal Reserve of land banks that relieved commercial banks of problematic farm mortgages and guaranteed new loans corresponding to standardization requirements. When the realtors and the sLAs lobbied for a national mortgage securitization system after wWI for the first time, the Farm Loan Act served as their guiding example. A second pillar of the Act allowed voluntary local credit cooperatives that would mutually guarantee their issued mortgage bonds, a system reminiscent of the German Landschaften but adapted to the American context. The century-old institutional heritage of modern German mortgage banks like the eighteenth century Landschaften, however, was lacking in post-colonial America. Imposed as a compulsory credit cooperative from above, often on noble landlords who felt strong ties to their localities, the Landschaften model was neither compatible with the transatlantic reservations about strong governmental measures nor with the nonexistence of a locally bound elite in a young society of small settlers [Frederiksen i 894b: 6o]. Thus, these cooperative banks for agricultural purposes could not serve as models, as they had in Germany, for the development of mortgage banks focused on urban real estate in the nineteenth century. More generally, the development of modern urban mortgage institutions seems to hinge upon early rural mortgage models that evolved into a centralized, bond-issuing model in urban Germany and a secondary mortgage market model in urban America that was created, standardized and guaranteed by the government. ${ }^{4}$

\footnotetext{
4 Our understanding of how different traditionally rural economic and welfare institutions spilled over into the urban
} 
FIGURE 2

Residential non-farm outstanding mortgages in million dollars

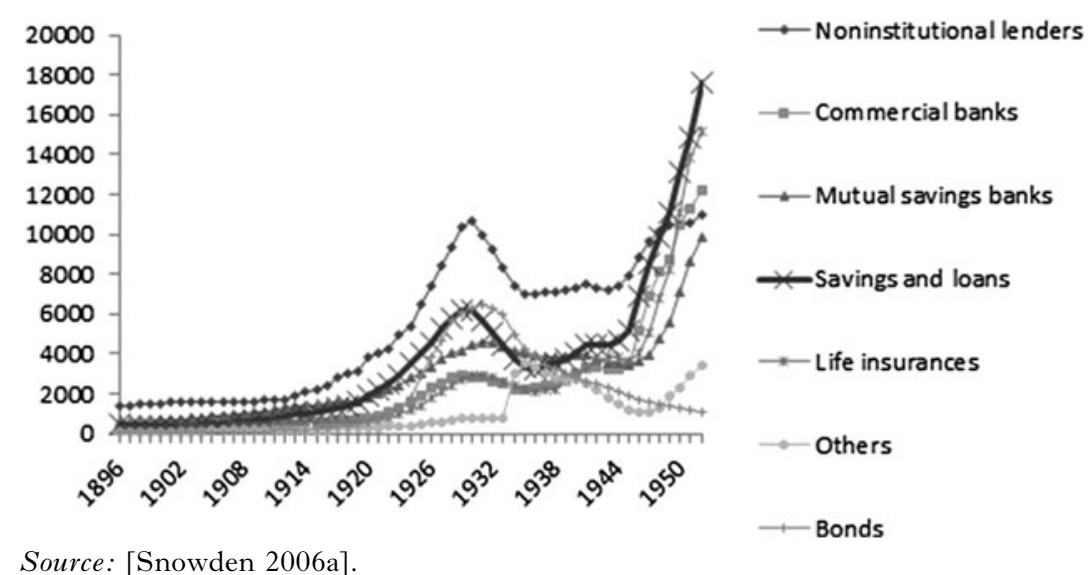

The last American mortgage-bond type to appear prior to the Great Depression emerged in the I920s and fueled the overproduction of apartment houses that ultimately led to the demise of this financing tool [Radford I996: I3f]. "The timing of the rental housing boom [I926I929] was greatly influenced by the growing popularity of mortgage bonds in the financing of rental housing" [Grebler I950: I32]. During that period, this new bond-based mode of financing led to the highest percentages of multifamily units in new construction in American building history, equaling up to 54 percent of all units. Usually the buildings were larger apartment projects, often in New York City [Baar I989: I I I]. In peak times, mortgage bonds reached a volume of several billion dollars, of which roughly half went into apartments and apartment hotels, while the remainder fueled business construction [Goetzmann and Newman 2010, White 2009]. Historically, the origins of bondissuing institutions, which mediated between the building companies in larger cities and private investors, lay in the 1904 legalization by New York State of the private mortgage insurance business since the elimination of the risk of default is a precondition of successful bond securitization. However, lax supervision, over-lending, and the oversaturation of the apartment market then led to the practical disappearance of this industry after the 1929 Wall Street crash. ${ }^{5}$ Figure 2 shows

5 This rise and decline paralleled the marfinance the building of commercial skyscrapers ket for bonds, issued by bond houses, to [Willis I995: I62]. 
the rise and fall of the bond curve and the general rise to dominance of the sLAs and thrift institutions.

The general absence of mortgage bonds in the United States prior to government intervention also reflects the prevailing regionalization of mortgage markets and the low degree of interregional lending even for non-securitized mortgages. Savings banks and the sLAs, which were the traditional urban mortgage lenders along with personal lending networks, were restricted by law to lend within their own region or state. Ethnic sLAs, in turn, focused on their respective neighborhoods; their concentration of risk was compensated by a precise knowledge of local conditions and of lenders, and by better monitoring mechanisms [Snowden I995a: 2I8]. The one exception to this rule of localism in mortgage lending was that of life insurance companies, which successfully managed to monitor local loan agents and enforce defaulting mortgages quickly. Life insurance companies held 60 percent of their assets in mortgages, sometimes up to ro percent directly in real estate, but gradually reduced their share to below I 5 percent in the twentieth century in favor of alternative investments in railroad and government bonds [Saulnier I950: I2]. While they held a high number of home mortgages (up to 90 percent in the early twentieth century), the volume of their investments in dollars was very directed towards income-producing residential and commercial mortgages (45 percent in I 946) [ibid. 49], known for long-term amortizing loans with high LTV ratios.

Thus, the lack of sufficient government regulation, the absence of a feudal mortgage-bank tradition, and the dominance of local depositbanking prevented the rise of an institution similar to the German mortgage banks.

\section{The dependence of governmental housing policy on existing institutions}

So far I have described how the basic housing institutions in Germany and the United States emerged in the nineteenth century. Although they undoubtedly received legal and sometimes even direct or indirect financial aid from governments, it would be misleading to talk of any government design behind the different institutional worlds that developed. German mortgage banks grew out of an initial desire to enhance agricultural credit. German cooperatives profited rather collaterally from the social insurance funds, which had 
obviously been set up for purposes other than housing. The first contact American sLas had with the federal government was the I 893 survey that documented their decade-long emergence and growth.

The history of the origins of American and German housing policies has already been written elsewhere [Schwartz 20I4a, Zimmermann I99I]. What is of particular interest here is to show that the principal government housing policies were determined by the preexisting institutional world once the postwar or Depression housing crises set in. I will therefore describe how the main government housing policy programs directly addressed features of those already existing institutions while ignoring others.

In the American case, the i93os saw the development of three major housing policy institutions: federal insurance for standardized mortgages, public housing, and a secondary mortgage market. The immediate reaction to the foreclosure problems after I929 was the establishment of the Home Owners' Loan Corporation (HOLC), which bought problematic mortgages from lenders, amongst them a considerable number from sLAs [Harriss I95I: 35]. The sLAs successfully lobbied in favor of supporting New Deal legislation and against any additional mortgage offers from the government that would crowd out private mortgages [Mason 2004: 96]. Both the publicly organized insurance of private mortgages through the Federal Housing Association of 1934 and the publicly organized resale of privately issued mortgages on a secondary market can be understood as merely complementary institutions that helped make the SLAs the financers of American postwar suburbanization. Another innovation financed generously by the federal government that made private mortgage products more attractive was the new opportunity to deduct mortgage costs from personal income taxes.

At the same time, American housing reformers attempted unsuccessfully to copy the European subsidy scheme for non-profit associations. Under the National Industrial Recovery Act, the Public Works Administration (PWA) created a housing division that adopted a limited-dividend subsidy program originating in President Hoover's Reconstruction Finance Corporation (RFC). In I932, the RFC had looked in vain for housing associations worthy of its subsidies and had found only one such association in New York. The subsequent PwA program suffered a similar fate when the Carl Mackley Homes of the American Federation of Full-Fashioned Hosiery Workers became its only completed housing project [Radford i996: iri]. The lack of adequate housing associations qualified to be the beneficiaries of subsidies outside of New York brought Harold Ickes, Secretary of the Interior, to 
rely on direct governmental top-down housing developments. Thus, the public housing administration had to build the first public housing units itself and had to initiate a new infrastructure of local housing authorities. Without an existing lobby on behalf of the housing movement and with high capital subsidy costs, the building of public housing became an easy target of cutbacks from the I950s onwards.

In the German case, the federal government began to intervene in the non-profit housing sector in the I920s and became much more heavily involved in the post-WwiI era, when the first Bausparkassen subsidies were also initiated. For the private rental apartments traditionally financed by mortgage banks, it became important to develop rent and tenancy regulations that simultaneously protected tenants and ensured financial profits. The Weimar Republic saw the first housingspecific tax legislation and the first non-profit housing credit programs. Union-associated cooperatives and building construction trades in particular became the main recipients of the public housing subsidies, which reached their peak between I 924 and I93 I. Thanks to government subsidies, the union-owned Neue Heimat became the largest real estate company in Germany until the r 980 s.

Bausparkassen savers received government subsidies in the course of the general attempt to mobilize more private capital in the I950s by promoting savings earmarked for housing construction through bonuses and income deductions on savings. The 1952 Wohnungsbauprämienrecht (housing subsidy legislation) initially provided saving bonuses for all kinds of savings related to housing investments, but it seemed tailored to the existing housing finance institutions [Pergande and Pergande i 973: I 83]. In its general pursuit to enable workers accumulate wealth, the government subsidized Bausparkassen savings. The idea was to encourage lower- and medium-income employees to accumulate savings earmarked for purchasing housing, and to have their employers contribute to workers' wealth formation by matching those funds [Kohlhase 20II: 4I]. In I 969, lower-income groups received additional bonuses, but the state subsidies were steadily reduced as of I 974 [ibid. I $27 \mathrm{f}$ ].

When it came to the financial sector, German housing policy was concerned with the incentive to save. Otherwise, the policy aims were to encourage the construction of rental housing units in the social and private sector. In the United States, however, most of the governmental housing budget was directed at supporting housing finance institutions. These differences in housing policy regimes are a direct reflection of the housing institutions predating the first housing laws in both countries. 


\section{Conclusion}

I started out by noting that Germany and the United States fall into opposing housing regime typologies in many respects. Particularly salient are the different percentages of homeowners and private and public tenants in their respective populations. In this article, I introduced a new explanatory factor to account for these differences, namely the history of housing finance institutions. More specifically, I addressed the question of why the United States developed an SLA-dominated system, while mortgage banks and the non-profit association circuit were more important in Germany. As housing form and tenure follow finance, these institutional differences were reflected in the housing stocks that were built in the countries during crucial phases of their urbanization. Housing stock in turn strongly correlates with tenure form in the two countries, i.e. single-family houses are dominantly owner-occupied, and apartments are rented. While the variations today between different housing finance systems have already been noted [Boléat I985], this article makes a new contribution by describing these systems' origins and their historical impact on housing regime differences.

To sum up: sLas tended to develop in non-banked areas and reflected the experience of pioneering American settlers, while the rise of a non-profit housing movement similar to the one in Germany was preempted by a lack of support from the labor movement, reformers, and the government as well as the absence of any kind of funding that might have existed had there been a social security system in the United States in the nineteenth century. Because the tradition of feudal mortgage banks was utterly lacking in the United States and the lending behavior of temporarily arising mortgage banks was not regulated, bond-financed mortgage banks did not emerge in the United States. In Germany, however, sLas were preempted by an existing banking network and the competing non-profit housing associations, which were supported by active municipalities, reformers, and eventually the government. Government housing policies, in turn, were built on the existing institutions. The Holc rescue bank, mortgage insurance, and the secondary mortgage market system mainly for sLAs in the United States were paralleled by a residual government-controlled public housing sector, since there was no non-profit housing movement. The German government subsidized non-profit housing and focused its homeowner subsidies on the ex-ante savings, which were mostly used by the members 
of Bausparkassen. Thus, US institutions gave the American housing policy a finance bias, while German institutions gave that country's housing policy a construction-subsidy bias.

The historic sequence of nineteenth century developments featuring limited-profit housing associations, rental-housing mortgage banks, and twentieth century sLas is paralleled by Austria, Switzerland, and France [Bouveret I 977], which copied the German Bausparkassen model in the I 93 os [Deutsch and Tomann I995], albeit to a much lesser degree in capital-rich, low-interest-rate Switzerland [SBG I 979: 30]. One of the persisting features of this Continental SLA model is the relatively high percentage of equity that households save prior to entering homeownership at an above-average age. Interestingly, mortgage banks based on the sale of covered bonds have never emerged in Belgium, where the predominant type of dwelling is small, owner-occupied houses [Doling and Elsinga 2013: 33].

At the same time, sLas spread through the English-speaking world. The first international congress of building societies that included the promotion of homeownership in their constitutions was almost exclusively frequented by members of English-speaking countries [Ewalt I 982, Price I 958: 454ff]. In most English-speaking countries, these institutions became the main financers of homeownership expansion [Donnison and Ungerson I 982: 2 I 2] - making up 35 percent of the twentieth century Australian market, for instance [Kemeny I 983: r 7f]. An independent tradition of non-profit housing cooperatives has yet to develop there [Kemeny i 98 I: 10$]$.

This article stresses the importance of reconsidering the differences in financial systems between countries-which have been much discussed with regard to capital investments in companies-from a new housing-finance perspective. If Germany's financial system is to be called bank-based and that of the United States market-based for company finance [Zysman I983], it is interesting to note that the housing finance constellation for the two countries is reversed: German mortgage banks channeled money from the anonymous capital market into the housing sector, whereas local deposit banks were the dominant actors in the United States. This article emphasizes how these differing constellations significantly impacted types of housing, forms of tenure and eventually the shape of cities. Given the importance of the housing sector in an economy with regard to savings, credit, and investment, future research should focus on other consequences of the differences between historical housing finance institutions in countries. Can the differences in these systems, 
for instance, explain cross-national differences in saving rates? How much do these systems contribute to the stability of countries in times of financial crisis? To what extent do these institutions channel capital into the housing sector, when compared with the sectors of industry, services or the state? Further inquiry into the composition and organization of historic mortgage markets of more countries could also promise a more encompassing typology along the lines proposed here.

\section{BI B LIOGRAPHY}

Arbaci Sonia, 2007. "Ethnic Segregation, Housing Systems and Welfare Regimes in Europe", International Fournal of Housing Policy, 7 (4): 40I-433.

Aschioff Gunther and Eckart Henningsen, 1995. Das deutsche Genossenschaftswesen: Entwicklung, Struktur, wirtschaftliches Potential (Frankfurt a.M., Knapp).

BAAR Kenneth Kalvin, I989. Explaining Crises in Rental Housing Construction Myth and Schizophrenia in Policy Analysis (ProQuest, UMI Dissertations Publishing).

Ball Michael, i990. Under One Roof. Retail Banking and the International Mortgage Finance Revolution (New York et al., Harvester Wheatsheaf).

Barlow James and Simon Duncan, I 994. Success an Failure in Housing Provision (Oxford, Elsevier Science).

Battilani Patrizia and Harm G. Schröter, 2012. "Introduction: Principal Problems and General Development of Cooperative Enterprise" in Battilani P. and H. Schröter, eds., The Cooperative Business movement, I95o to the Present (Cambridge, Cambridge University Press: I-I 9).

Bauer Catherine, I974. Modern Housing (New York, Arno Press).

Behrens Carl F., I952. Commercial Bank Activities in Urban Mortgage Financing (New York, National Bureau of Economic Research).

Benevolo Leonardo, I971. Die sozialen Ursprünge des modernen Städtebaus. Lehren von gestern-Forderungen für morgen (Gütersloh, Bertelsmann Fachverlag).

BLock Alexander, I93I. Bausparen in England, Amerika und Deutschland (Berlin, Bauwelt-Verlag).
BoDfish Henry Morton, I93I. History of Building and Loan in the United States (Chicago, United States Building and Loan League).

BoléAT Mark, I985. National Housing Finance Systems. A Comparative Study (London et al., Croom Helm).

Bouveret Andreas Michael, i977. Das Bausparwesen in Frankreich. Entwicklung, Struktur und gegenwärtige Bedeutung im Rahmen des französischen Immobiliarkredits (Würzburg, Physica-Verlag).

BüHLER Hans-Dieter, I965. Die Savings and Loan Associations, unter besonderer Berücksichtigung ihres Vergleichs mit den Bausparkassen (University of Mannheim, PhD Diss.).

Bullock Nicholas and James READ, I 985. The Movement for Housing Reform in Germany and France I84O-I9I4 (Cambridge, Cambridge University Press).

Castles Francis G. and Maurizio Ferrera, I 996. "Home Ownership and the Welfare State: Is Southern Europe Different?", European Society and Politics, I (2): I 63 - I 85 .

Clark Christopher, 2007. Preußen. Aufstieg und Niedergang I600-I947 (München, Deutsche Verlags-Anstalt).

Clemens Gabriele B. and Daniel Reupke, 2008. "Kreditvergabe im r9. Jahrhundert zwischen privaten Netzwerken und institutioneller Geldleihe" in Clemens G. B., ed., Schuldenlast und Schuldenwert. Kreditnetzwerke in der europäischen Geschichte I300-I9oo (Trier, Kliomedia: 2 I I-238).

Cromley Elizabeth C., I990. Alone Together. A History of New York's Early Apartments. (Ithaca, Cornell University Press). 
Daunton Martin J., 2007. "Home Loans versus Council Houses: The Formation of American and British Housing Policy, I 900I920", Housing Studies, 3 (4): 232-246.

-, I988. "Cities of Homes and Cities of Tenements: British and American Comparisons I870-1914", Fournal of Urban History, I4: 283-3 I9.

—, I990. "Rows and Tenements: American Cities, I880-I9I4" in Daunton M. J., ed., Housing the Workers, I85o-I9I4. A Comparative Perspective (London, Leicester University Press: 249-286).

Deutsch Edwin and Horst Tomann, I 995. "Home Ownership Finance in Austria and Germany”, Real Estate Economics, 23 (4): 44I-474.

Deutschebundesbank, i 976 . Deutsches Geld- und Bankwesen in Zahlen I876-1975 (Frankfurt a.M., Fritz Knapp GmbH).

Diamond Douglas B. and Michael J. LeA, I 992. "The Decline of Special Circuits in Developed Country Housing Finance”, Housing Policy Debate, 3 (3): 747-777.

Doling John and Marja Elsinga, 20I3. Demographic Change and Housing Wealth. Home-owners, Pensions and Asset-based Welfare in Europe (Dordrecht, Springer).

Donnison David, i967. The Government of Housing (Harmondsworth, Penguin).

Donnison David and Clare Ungerson, 1982. Housing Policy (Harmondsworth, Penguin).

- I901. Der deutsche Kapitalmarkt. (Leipzig, Duncker \& Humblot).

-, r920. Handbuch des Wohnungswesens und der Wohnungsfrage (Jena, Fischer).

Effosse Sabine, 2003. L'invention du logement aidé en France. L'immobilier au temps des Trente Glorieuses (Paris, Comité pour l'Histoire économique et financière de la France).

Ewalt Josephine, I982. Nation to Nation. Nurturing Homeownership. A History of the International Union of Building Societies and Savings Associations I9I4-I980 (Chicago, International Union of Building Societies and Savings Associations).

FAller Bernhard, 200I. Hemmnisse der Wohneigentumsbildung. Forschungsbericht im Auftrag des Bundesamtes für Bauwesen und Raumordnung (Bonn, Bundesamt für Bauwesen und Raumordnung).

Fishback Price, Jonathan Rose and Kenneth SNOWDEN, 20I3. Well Worth Saving. How the New Deal Safeguarded Home
Ownership (Chicago, University of Chicago Press).

Fishman Robert, I987. Bourgeois Utopias. The Rise and Fall of Suburbia (New York, Basic Books).

FItrakis Robert John, I990. The Idea of Democratic Socialism in America and the Decline of the Socialist Party : Eugene Debs, Norman Thomas and Michael Harrington (ProQuest, UMI Dissertation Publishing).

Foner Eric, I984. "Why Is There No Socialism in the United States?", History Workshop, I 7: 57-80.

Frederiksen D. M., i 894 a. "Mortgage Banking in America", Fournal of Political Economy, 2 (2): 203-234.

-, I 894b. "Mortgage Banking in Germany", Fournal of Political Economy, 9 (I): 47-76.

Fuchs C. J., 1929. "Die Finanzierung des Wohnungsneubaues durch die Sparkassen” in Kumpmann K., ed., Sparkassen und Wirtschaft (Essen-Ruhr, Baedeker: 42-66).

FüHrer Karl Christian, I 999. "Die Rechte von Hausbesitzern und Mietern im Ersten Weltkrieg und in der Zwischenkriegszeit. Frankreich, Großbritannien und Deutschland im Vergleich" in Siegrist H. and D. Sugarman, eds., Eigentum im internationalen Vergleich (I8.-20. Fahrhundert) (Göttingen, Vandenhoeck \& Ruprecht: 225-244).

Garb Margaret, 2005. City of American Dreams. A History of Home Ownership and Housing Reform in Chicago, I87II9I9 (Chicago/London, The University of Chicago Press).

Garon Sheldon M., 2012. Beyond Our Means. Why America Spends While the World Saves. (Princeton/Oxford, Princeton University Press).

Glatzer Wolfgang, I980. Wohnungsversorgung im Wohlfahrtsstaat. Objektive und subjektive Indikatoren zur Wohlfahrtsentwicklung der Bundesrepublik Deutschland. (Frankfurt/New York, Campus).

Goetzmann William N. and Frank Newman, 2010. "Securitization in the I920's", NBER Working Paper, I 5650.

Grebler Leo, 1950. Production of New Housing: A Research Monograph on Efficiency in Production (New York, Social Science Research Council).

Harloe Michael, i 995. The People's Home? Social Rented Housing in Europe and America (Oxford, Blackwell). 
Harris Richard and Chris Hamnett, I 987. "The Myth of the Promised Land: The Social Diffusion of Home Ownership in Britain and North America", Annals of the Association of American Geographers, 77 (2): I73-I90.

Harris Richard, I 989. "The Family Home in Working-Class Life", Research Paper, Centre for Urban and Community Studies, University of Toronto.

Harriss C. Lowell, i 95 I. History and Policies of the Home Owners' Loan Corporation. (New York, NBER).

Haveman Heather A. and Hayagreeva RaO, I997. "Structuring a Theory of Moral Sentiments: Institutional and Organizational Coevolution in the Early Thrift Industry”, I 02 (6): I606-г65I.

Haveman Heather A., Hayagreeva RaO and Srikanth Paruchuri, 2007. "The Winds of Change. The Progressive Movement and the Bureaucratization of Thrift", American Sociological Review, 72 (I): I I 7-I42.

Hays Samuel Pfrimmer, 1957. The Response to Industrialism I885-I9I4 (Chicago, University of Chicago Press).

Hoekstra J., 2005. "Is There a Connection between Welfare State Regime and Dwelling Type? An Exploratory Statistical Analysis", Housing Studies, 20 (3): 475-495.

Horsthemke Ansgar, 1998. Die Genossenschaften in den USA unter besonderer Berücksichtigung der New Generation Cooperatives (Stuttgart-Hohenheim, Arbeitspapiere der Forschungsstelle für Genossenschaftswesen an der Universität Hohenheim).

JeNkis Helmut W., I973. Ursprung und Entwicklung der gemeinnützigen Wohnungswirtschaft. Eine wirtschaftliche und sozialgeschichtliche Darstellung (Bonn, Domus-Verl. et al.).

Kaelble Hartmut, I 99i. Nachbarn am Rhein. Entfremdung und Annäherung der französischen und deutschen Gesellschaft seit I880 (München, C. H. Beck).

KarIN Jean Roberta, I947. Cooperative Housing in the United States. (ProQuest, UMI Dissertation Publishing).

Kemeny Jim, r981. The Myth of Home Ownership. Private Versus Public Choices in Housing Tenure. (London, Routledge).

-, I983. The Great Australian Nightmare. A Critique of the Home-Ownership Ideology. (Melbourne, Georgian House).

Kemeny Jim and Stuart Lowe, 2005. "Schools of Comparative Housing Research: From
Convergence to Divergence", Housing Studies, I3 (2): I6 I-I 76.

Kluge Arnd, I991. Geschichte der deutschen Bankgenossenschaften. Zur Entwicklung mitgliederorientierter Unternehmen (Frankfurt a.M., Knapp).

Kohlhase Rudolf, 20 I I. Die Entwicklung des Bausparwesens in der Bundesrepublik Deutschland in der Zeit zwischen 1949 und I99o. Eine institutionenökonomische Analyse (Köln, Dissertation).

LEA Michael, I996. "Innovation and the Cost of Mortgage Credit: A Historical Perspective", Housing Policy Debate, 7 (I): I 47-I 74

Lintner John, I948. Mutual Savings Banks in the Savings and Mortgage Markets. (Boston, Graduate School of Business Administration).

Lipset Seymour Martin and Gary Marks, 2000. It Didn't Happen Here. Why Socialism Failed in the United States (New York, Norton).

Lubove Roy, 1962. The Progressives and the Slums. Tenement House Reform in New York City I89o-I9I7 (Pittsburgh, University of Pittsburgh Press).

-, I963. Community Planning in the I920's: The Contribution of the Regional Planning Association of America (Pittsburgh, University of Pittsburgh Press).

Lynd Robert S. and Helen M. Lynd, 1929. Middletown. A Study in Contemporary American Culture (London, Constable).

Mason David L., 2004. From Buildings and Loans to Bail-outs: A History of the American Savings and Loan Industry, I83I1995 (Cambridge, Cambridge University Press).

-, 2014. The American Savings and Loan Industry, I83I-I935. Volume 4. Serving the People: Women, Immigrants, African Americans and the Promotion of Home Ownership (London, Pickering \& Chatto).

McDonnell Timothy L., I 957. The Wagner Housing Act: A Case Study of the Legislative Process (Chicago, Loyola University Press).

Müller Martin L., I999. Bausparen in Deutschland zwischen Inflation und Währungsreform I924-I948 (München, C. H. Beck).

Pergande Hans-Günther and Jürgen Pergande, 1973. Die Gesetzgebung auf dem Gebiete des Wohnungswesens und des Städtebaues (Frankfurt a.M., Weisbecker).

PiketTy Thomas and Gabriel Zucman, 2013. "Capital is Back. Wealth-Income Ratios in 
Rich Countries I700-2010”, Paris School of Economics.

Prasad Monica, 2012. The Land of Too Much. American Abundance and the Paradox of Poverty (Cambridge, Harvard University Press).

Price Seymour J., I958. Building Societies. Their Origin and History (London, Franey).

Puhle Hans-Jürgen, i975. Politische Agrarbewegungen in kapitalistischen Industriegesellschaften. Deutschland, USA und Frankreich im 20. Fahrhundert (Göttingen, Vandenhoeck \& Ruprecht).

RAdFord Gail, i996. Modern Housing for America. Policy Struggles in the New Deal Era. (Chicago et al., The University of Chicago Press).

Redenius Oliver, 2009. Strukturwandel und Konzentrationsprozesse im deutschen Hypothekenbankwesen (Wiesbaden, Gabler).

Reuter Hans-Georg, I 980. "Verteilungs- und Umverteilungseffekte der Sozialversicherungsgesetzgebung im Kaiserreich" in Blaich F., ed., Staatliche Umverteilung in historischer Perspektive (Berlin, Duncker \& Humblot: 107-163).

Rogers Daniel T., 1998. Atlantic Crossings. Social Politics in a Progressive Age (Cambridge, The Belknap Press of Harvard University Press).

Saulnier Raymond J., I950. Urban Mortgage Lending by Life Insurance Companies (New York, National Bureau of Economic Research).

SвG, I 979. Die Schweiz-ein reiches Volk von Mietern. Zur Frage des Mietwohnens und des Wohnungseigentums in der Schweiz (Zürich, Schweizer Bankgesellschaft).

Schmidt Hans Walter, r993. "Die Hypothekenbanken" in Rüchardt K., ed., Handbuch des Hypothekarkredits. Immobilienfinanzierung in Deutschland und Europa (Frankfurt a.M., Fritz Knapp: I O2 I- I 058 ).

SchneIDer Michael, i989. Kleine Geschichte der Gewerkschaften: ihre Entwicklung in Deutschland von den Anfängen bis heute (Bonn, Dietz).

SchönmanN Hans-Günther, I 993. "Geschichte des deutschen Hypothekarkredits" in Rüchardt Konrad, eds., Handbuch des Hypothekarkredits. Immobilienfinanzierung in Deutschland und Europa (Frankfurt a.M., Fritz Knapp: 8 I 9-98I).

Schratz Sabine, 20 I . Das Gift des alten Europa und die Arbeiter der Neuen Welt. Zum amerikanischen Hintergrund der
Enzyklika Rerum novarum (I89I) (Paderborn et al., Ferdinand Schöningh).

Schwartz Alex F., 2014a. Housing Policy in the United States (New York, Routledge).

Schwartz Herman, 20 I 4 b. "Is There a Really Big Trade-Off? Housing, Welfare and Pensions Reconsidered from a Balance Sheet Perspective", http://www.people. virginia.edu/ hms $2 f$.

Schwartz Herman and Leonard Seabrooke, 2008. "Varieties of Residential Capitalism in the International Political Economy: Old Welfare States and the New Politics of Housing”, Comparative European Politics, 6: 237-26r

Siegler Richard and Herbert J. Levy, I 987. "Brief History of Cooperative Housing", National Association of Housing Cooperatives, I 2: I4-I 9.

Simon Roger D., I 996. "The City-Building Process: Housing and Services in New Milwaukee Neighborhoods I880-1910”, Transactions of the American Philosophical Society, 86 (6): I - I63.

Sкосрог Theda, Marshall Ganz and Ziad Munson 2000. "A Nation of Organizers: The Institutional Origins of Civic Voluntarism in the United States", The American Political Science Review, 94 (3): 527-546.

Snowden Kenneth A., I 995a. "The Evolution of Interregional Mortgage Lending Channels, I870-1940: The Life Insurance-Mortgage Company Connection" in Lamoreaux N. R. and D. M. G. Raff, eds., Coordination and Information: Historical Perspectives on the Organization of Enterprise (Chicago, University of Chicago Press: 209-256).

—, r 995 b. "Mortgage Securitization in the United States: Twentieth Century Developments in Historical Perspective" in Bordo M. D., ed., Anglo-American Financial Systems (Burr Ridge, IL et al., Irwin: 26I-298).

-, I997. "Building and Loan Associations in the U.S., I $880-1893$ : the Origins of Localization in the Residential Mortgage Market", Research in Economics, 5i: 227-250.

-, 2003. "The Transition from Building and Loan to Savings and Loan, I890-1940" in Engerman S. L. and L. E. Davis, eds., Finance, Intermediaries, and Economic Development (Cambridge, Cambridge University Press: 1 57-206).

-, 2006a. "Debt on nonfarm structures, by type of debt, property, and holder: 
I 896-I952. Table Dc903-928” in Carter S. B. et al., eds., Historical Statistics of the United States, Earliest Times to the Present: Millennial Edition (New York, Cambridge University Press.

-, 2006b. "Occupied Housing Units, by Farm Status, Urban Location, Region, Race, Ethnicity, and Ownership: I890-I 997 (Table Dc697-760)" in Carter S.B. et al., eds., Historical Statistics of the United States, Earliest Times to the Present: Millennial Edition (New York, Cambridge University Press).

-, 2007. "Mortgage Companies and Mortgage Securitization in the Late Nineteenth Century", Manuscript, University of North Carolina at Greensboro. Sonnemann L. and Fr. A. Lange, i 865. federmann Hauseigenthümer. Das bewährteste System englishcer Baugenossenschaften für deutsche Verhältnisse bearbeitet und in seiner Verwendbarkeit für Arbeiter-Genossenschaften jeder Art nachgewiesen (Duisburg, W. Falt \& Volmer).

Sutcliffe Anthony, i98I. Towards the Planned City. Germany, Britain, the United States and France I780-I9I4 (New York, St. Martin's Press).

Tennstedt Florian, 1981. Sozialgeschichte der Sozialpolitik in Deutschland. Vom I8. Fahrhundert bis zum Ersten Weltkrieg (Göttingen, Vandenhoeck \& Ruprecht).

Turner Frederick Jackson, I 920. The Significance of the Frontier in American History (New York, Henry Holt).

Unterstell Rembert, I989. Mittelstand in der Weimarer Republik. Die soziale Entwicklung und politische Orientierung von Handwerk, Kleinhandel und Hausbesitz I9I9-I933. Ein Überblick (Frankfurt a.M., Peter Lang).

VDH , I 999. Ioo fahre Hypothekenbankgesetz. Textsammlung und Materialien (Verband deutscher Hypothekenbanken).

Voigtländer Michael, 2009. "Why Is the German Homeownership Rate So Low?", Housing Studies, 24 (3): 355-372.

-, 2008. Wirtschaftsfaktor Immobilien. Die Immobilienmärkte aus gesamtwirtschaftlicher
Perspektive. (Berlin/Wiesbaden, Deutscher Verband für Wohnungswesen, Städtebau und Raumordnung e.V./Gesellschaft für Immobilienwirtschaftliche Forschung e.V.).

Von SAldern Adelheid, I979. "Kommunalpolitik und Arbeiterwohnungsbau im Deutschen Kaiserreich" in Niethammer Lutz, ed., Wohnen im Wandel (Wuppertal, Hammer: 344-362).

—, I 997. "Social Rationalization of Living and Housework in Germany and the United States in the I920s", History of the Family, 2 (I): 73-98.

Wandschneider Kirsten, 20I3. "Lending to Lemons: Landschafts-Credit in I8th Century Prussia", NBER Working Paper, I9I 59 .

White Eugene N., 2009. "Lessons from the Great American Real Estate Boom and Bust of the I920s", NBER Working Paper, I 5573 .

Willis Carol, i 995. Form Follows Finance. Skyscrapers and Skylines in New York and Chicago. (New York, Princeton Architectural Press).

Wright Gwendolyn, I983. Building the Dream. A Social History of Housing in America. (Cambridge, MA, MIT Press).

Zensus, 20I I. https://ergebnisse.zensus2oI I.de.

ZimMermanN Clemens, ig9i. Von der Wohnungsfrage zur Wohnungspolitik: die Reformbewegung in Deutschland I845-I9I4 (Göttingen, Vandenhoeck \& Ruprecht).

ZuCKer Lynne G., I986. "Production of Trust: Institutional Sources of Economic Structures, I 840-1920" in Staw B.M. and L.L. Cummings, eds., Research in Organizational Behavior, Vol. 8 (Greenwich, JAI Press: 53-I I I).

Zunz Oliver, 1982. The Changing Face of Inequality: Urbanization, Industrial Development, and Immigrants in Detroit, I880-I920 (Chicago, University of Chicago Press).

Zysman John, I983. Governments, Markets, and Growth. Financial Systems and the Politics of Industrial Change. (Oxford, Robertson). 


\section{Résumé}

La littérature comparée consacrée aux régimes de production et de protection sociale a jusqu'à présent négligé les différences considérables entre pays dans le domaine du logement. Les États-Unis sont devenus, au cours du $\mathrm{XX}^{\mathrm{e}}$ siècle, un pays de propriétaires vivants majoritairement dans des villes et dans des maisons individuelles. La politique américaine a soutenu l'endettement privé pour le logement avec une part de logement public résiduel. L'Allemagne, au contraire, est restée un pays de locataires avec des villes composées de bâtiments collectifs. La politique allemande a soutenu des associations à but non lucratif et une forte incitation à l'épargne logement. L'article envisage ces différences comme le résultat d'une histoire institutionnelle qui débute au $\mathrm{XIX}^{\mathrm{e}}$ siècle. L'Allemagne a développé des associations de logement à but non lucratif et a financé le logement par l'intermédiaire de banques hypothécaires, tous deux privilégiant la construction d'appartements locatifs. Aux ÉtatsUnis, les associations d'épargne et de crédit ont favorisé le recours à des prêts hypothécaires pour les propriétaires-occupants, et ce faisant la construction de maison individuelles. Lorsque les gouvernements interviennent au cours de la crise du logement dans les années I920-I930, leurs soutiens au logement passent par ces institutions préexistantes. Ainsi, la politique américaine de logement tend-elle à privilégier les associations d'épargne et de crédit, là où l'Allemagne soutient les coopératives d'habitation.

Mots-clés : Logement ; Accession à la propriété ; Institutions historiques ; Financement du logement ; Réforme du logement.

\section{Zusammenfassung}

Zusammenfassung Die vergleichende Wohlfahrts- und Kapitalismusforschung hat bisher weitgehend die bedeutenden Länderunterschiede im Wohnungssektor vernachlässigt. So wurden auf der einen Seite die USA im Laufe des 20. Jahrhunderts ein Land von Hauseigentümern, die zumeist in Einfamilienhausstädten wohnen, und die amerikanische Wohnungspolitik wurde vor allem eine Förderung der privaten Hypothekenwirtschaft mit bloß residualem Sozialwohnungsbau. Deutschland, auf der anderen Seite, ist ein mieterdominiertes Land mit Mehrfamilienhausstädten geblieben. Seine Wohnungspolitik war eher auf die Subvention von gemeinnützigen Wohnungsgenossenschaften und auf die Förderung von Bausparen ausgerichtet. Der Artikel behauptet, dass diese Unterschiede auf schon im r9. Jahrhundert angelegte Unterschiede von Institutionen im Wohnungssektor zurückführbar sind. Deutschland entwickelte darin Baugenossenschaften und Hypothekenbanken, die beide tendenziell Mietwohnungsbau unterstützten, wohingegen sich in den USA Bausparvereine entwickelten, die tendenziell eigentümerbewohnte Einfamilienhausbauten unterstützten. Mit Einsetzen der ersten dezidierten Wohnungspolitiken in den 1920/3oern bauten die Staaten weitgehend auf den schon existierenden Institutionen auf. Auf diese Weise wurde die amerikanische Wohnungspolitik eine Förderung des privaten Hypothekenmarktes, die deutsche hingegen eine Subventionierung von gemeinnützigen;

Schlagwörter : Wohnungsunternehmen; Wohnungswirtschaft; Hauseigentum; Historische Institutionen; Hauskredit; Wohnungsreform. 